\title{
Examining change management theories through case studies
}

\author{
Prabir Kumar Bandyopadhyay, Sankar Ghosh \\ Former Professor and Independent researcher \\ General Manager- Quality HaldynHeinz Fine Glass, Gujarat,India
}

\begin{abstract}
The objective of the present paper is to examine the already established change management success factors and respective theories, in the light of personal experience in five organizations as a change agent. And examine whether these theories are sufficient to explain the success and failure of change management in Indian organisations. We took the constructivists approach while studying the change management phenomenon. Hence, we relied on a qualitative method. As there is no single truth, the reality needs to be interpreted and the truth discovered based on the collective experiences of the researchers. Therefore, the theoretical perspective of our research is interpretivism. We have used narrative inquiry based on memory as we have first-hand knowledge over a period in each of the five cases and in some cases; we both have experience in a different time period. This approach is appropriate in this case of knowledge of change management, which is unquantifiable and where it is not easy to transfer the experience. Our findings mostly support the existing theories and steps in change management. Out of the ten steps one step is "“Form partnership with stakeholders for guiding coalition" is not supported. Existence of good management practices are a perquisite for a successful change. Institutionalize change is an important step. As there is a gap between observation and articulation of this paper there are chances of missing important observations that could have considered for drawing more insightful conclusion. The study is based on individual's observation therefore it may have cognitive biases. The case study narratives will give an insight to a practitioner how different organisations management change management process. The findings presented will also be helpful to a practitioner. The strongest new finding is the need to have the good management practices in place before going ahead with change.
\end{abstract}

Key words: Change Management, TPM, Sixsigma, Case study, PRISMA, Systematic review, Appreciative Inquiry, Kotter's eight step theory, Narrative inquiry

\section{Introduction}

'Only change is constant' is the most used phrase in management parlance. All companies try to take some initiatives as a means of bringing change in the organization for different objectives, either for cost reduction or culture change or for both. Only 20 percent of change management projects succeed, (Change management, inside job, 2001). In spite of high chances of failure, change management initiatives gaining popularity (Barneds et al., 2013). Some of the widely used organizational change initiatives are Quality Circle, Total Quality Management (TQM), Total Productive Maintenance, KAIZEN, Six Sigma, Problem solving, Human capacity building and Business Excellence (ibid). If we look back, we see these initiatives come in waves. Google trends indicate there is a 75 percent reduction in the search volume of 'Quality Circle' since 2004, 80 percent reduction in the case of 'Total Productive Maintenance,' 75 percent in the case of Six Sigma, and 85 percent reduction in the case of 'TQM.' In the case of MBNQA (Malcom Baldrige National Quality Award), the facts are most disturbing. The award was originally designed for manufacturing industries, but participation from manufacturing organizations in the USA has come down to a single digit. Conversely, anecdotal evidence suggests that these are the most popular approaches used by organizations in India for bringing change. 
We have worked in four organizations as a change agent/change facilitator for one to five years. There are two organizations where we both have worked in a different period. We thought of reflecting on our individual experience and tried to get the answer to the age-old question - in bringing change, why are some organisations successful, and some are not? But it has always been raised and answered either by consultants and academicians. Published papers by practitioners are scarce.

What was happening in these organizations has been presented in this paper in a story format using a narrative inquiry from our memory. Qualitative data analysis was carried out. We then examined our findings in the light of all the theories on change management that exist in the extant literature with the objective to find out to what extent these theories are evidenced from our case studies.

\section{Existing theories}

There exists huge number of papers on change management in the extant literature. Barned et al (2013) found 20,000 plus papers in the published literature. Instead of reviewing individual papers we decided to review the systematic review articles on change management as such review articles consider all the relevant articles available in data bases. We found only two such articles. Barneds et al., (2013) conducted systematic review following the specifications in the Preferred Reporting Items for Systematic Reviews and MetaAnalyses (PRISMA) statement (Moher, Liberati, Tetzlaff, \& Altman, 2010). They studied 1295 studies in two phases. Stouten et al., (2018) reviewed 95 articles concerning empirical studies and reviews pertaining to change management theories and practices. They have considered seven most referred prescriptive models based on web of science citations and google web hits. We feel that both the studies have covered large number of articles, reviews and meta-analysis and we considered these two sources for reviewing the change management theories, models and practices in our study. We find theories, model, steps and practices are used interchangeably in the extant literature. Stouten et al., (2018) have reviewed seven prescriptive change models and these are, Lewin's Three-Phase Process (Sarayreh, B.H, Hassan J A, Barakat A E.2013 ); Beer's Six-Step Change Management Model ( Beer,1980); Appreciative Inquiry (AI) (Cooperrider and Srivastva ,1987); Judson's Five Steps (Arnold S. Judson,1991); Kanter, Stein, and Jick's Ten Commandments (Rosabeth Moss Kanter, Barry Stein, and Todd Jick,1992), Kotter's Eight-Step Model (John Kotter ,1996); Hiatt's ADKAR Model (Hiatt Jeff ,2006). Price et al., (2003) in their article "The psychology of change management," proposed four basic conditions for brining organizational change: a) a compelling story b) role modeling; c) Reinforcing Mechanisms; and d) capability building. Stouten et al., (2018) synthesized ten steps by reviewing seven prescriptive models. These steps are presented in Table 1. Stouten et al., (2018) have also verified each success factor / step against scientific evidence. Table 1 also presents the scientific evidence behind each step/ success factor.

The objective of the present paper is to examine the already established change management success factors and respective theories against the findings from five case studies so as to verify whether these steps and theories are sufficient to explain the success and failure of change management in Indian organisations.

\section{Research Methodology \\ Ontology}

We believe that there is no single reality behind success or failure of a change management approach in organizations. It is highly contextual, and individuals and groups create the reality. Therefore, we took the constructivists approach while studying the change management phenomenon. Hence, we relied on a qualitative method.

\section{Epistemology}

As there is no single truth, the reality needs to be interpreted and the truth discovered is based on the collective experiences of the researchers. Therefore, the theoretical perspective of our research is interpretivism. We also believe that as we have personal experience for a long time as a change agent (actor) in different organizations, which are included in the paper as case examples and in two cases we both have worked in a different period, this approach will be more appropriate as we know the context. Thus, we can avoid losing sight of the surrounding historical context, which many researchers have thought to be the weakness of the interpretivism approach (Stake, 1995; Doolin, 1996). 


\section{Methods}

We have used narrative inquiry based on memory as we have first-hand knowledge over a period of time in each case, and in some cases, we both have work experience in a different time period. This approach is appropriate in the case of knowledge of change management, which is unquantifiable and where it is not easy to transfer the experience.

Clark and Chalmers (1998) hypothesise that narratives that are recollected from one's experience while working in respective organizations and memory (in this case, our first-hand perception) are cognitively indistinguishable and are thereby effective in transferring knowledge.

Narrative inquiry is based on the epistemological assumption that the human mind makes sense of complex multi-causal experience through story structures. Thus, it is often more engaging to the audience and useful than other forms of social inquiry (Cole, et.al., 2001; Bell, 1999).

\section{Cases}

\section{Max Steel (Name changed)) and Indo German Tubes (Name changed)}

Both the organizations are a part of a large group under the same chairman. The chairman sits in his London office and is one of the most ardent advocates of the two leading improvement levers, Total Productive Maintenance (TPM) and Six Sigma. He has remarkable faith in these two tools and displays the high level of commitment and energy whenever he interacts with the plant team. There is a dedicated cell for TPM and Six Sigma under Business Excellence. Both the organizations have adopted the Japan Institute of Plant Management's (JIPM) TPM approach and have obtained the different levels of certification from JIPM. The company is also participating in Business Excellence Awards based on EFQM/MBNQA frame work. Operations of both the plants are labour intensive.

\section{Max Steel}

Frontline supervisors of Max Steel, an alloy manufacturing unit in Eastern India, are thoroughly trained on each initiative. And each initiative has a goal. For example, the purpose of TPM was to attain the different levels of JIPM's TPM Award. In the case of Six Sigma, all functions are supposed to propose a project with a business case. In the case of KAIZEN there used to be a target number of KAIZEN suggestions for each department. Involvement of each managerial position up to front-line supervisors is ensured by incorporating appropriate KPI in the performance management system. Operator level engagement is achieved through KAIZEN and the suggestion scheme. These initiatives were taken as a part of the usual business process and used to be reviewed along with other business activities during the monthly meeting, chaired by a senior board member, audit committee and senior executives. Any significant issues identified during the meeting are assigned to TPM or Six Sigma initiatives as appropriate. The claims of any improvement resulting from TPM or Six Sigma projects used to be audited by second party internal auditors before the closure of the respective projects. Standard Operating Procedures (SOP) were documented for each business process, and the Sigma level of each SOP was determined. The Sigma level for each SOP used to be reported to the chairman. All these initiatives have been running successfully for the last 15 Years.

\section{Indo German Tubes}

Indo German Tubes is the second unit of the group under the same Chairman. The firm is engaged in producing GI Pipes. There is a mechanism in place to review the status of the improvement projects by the plant management and weekly review of the projects in the presence of their reporting managers by the chairman in a video conference. The TPM drive has been in place over the last decade while the Business Excellence (BE) is over five years. The commitment of the plant head and most of the head of functions towards the initiatives are not visible. The organization picks up much more than a rational number of projects possible for the size of its operations. The primary reason is the relentless push from the chairman. Besides the above two drives, the unit is having multiple management systems made compliant to international standards. Surprisingly in the case of continuous improvement projects in the area of KAIZEN, and suggestion schemes, mainly carried out by workmen, was a huge success. Here is a case where the management could engage the workmen more than the supervisor level and above. The management team at the unit level was paying lip service to the Chairman. Projects are selected not based on the business process performance metric, and the project metrics are not aligned with the process metric. It was difficult to define 
the success of the project because of this disconnect. As a part of the top management, we tried to bring home the point but were not successful in bringing the necessary alignment. The project facilitators, the black belt for the Six Sigma and TPM leaders become the subject of continual review by the plant management. The facilitators get squeezed between the unwilling project leaders supported by their respective heads and the Chairman. As a result, the facilitators become compilers of fictitious project reports. On the TPM front, TPM leaders come under massive pressure from the Chairman. Every Tuesday they present the status of implementation of TPM in different areas with pre-post scenarios. The expectation of the Chairman was very high. The plant management could not present the realistic pictures of the ground level in fear of displeasing the Chairman. Therefore, the false stories kept building up and fiction started getting a more prominent share of the cases in every subsequent wave of projects. This fear factor resulted in a disproportionate amount of stress in the system and in the change agents and the plant manager which is evident in high turnover of employees at the managerial level in TPM, BE, and HR including the plant head at this unit, while it is quite stable in Max Steel.

\section{Pan India Glass (Name changed)}

The company is a multi-unit type III glass packaging manufacturer and is the undisputed market leader in India having manufacturing setups in all four sides of the vast country to access the remotest part of the market. The manufacturing units are highly labour intensive. The company is a family owned entity and used to be managed by the founder chairman with the assistance of two sons looking after the six units as Managing Director (MD). The chairman was an octogenarian and was not too enthusiastic about modern managerial practices. He used to concentrate mainly on the core process of glass making, which was his passion. The younger sibling was always striving to implement some initiatives e.g. TPM, Six Sigma. Until 2009, the flagship unit of the company at Eastern India had worked on total productive maintenance (TPM) under the banner of the area effectiveness team (AET) with assistance from a consulting body. The representative of the consultant, stationed at the unit, acted as coordinating assistant for preparing documentation and preparing the presentations on behalf of the Head of Departments (HOD), who had no interest in anything other than the routine activities and pleasing the young proprietor during occasional reviews. They also had a General Manager - Head of Initiative, a one-person department, to look after the TPM related activities. It was predominantly a paper exercise. The company discontinued the consultant. They took up Six Sigma, and another consulting body was engaged. The newly appointed consultant took the COPQ (Cost of Poor Quality) approach and based on the cost of poor quality, identified thirteen improvement projects. The freshly appointed consultant imparted training to the select executives without awarding any 'level.' Each functional HOD was the project leader, and respective departmental supervisors were members. Soon after the engagement of the consultant the HOD of the initiative department left the organization. There was nobody to coordinate with the consultant. At this juncture, one of us joined as the HOD of the initiative department. He was given the job to revamp the TPM activities and also to give momentum to the Six Sigma initiative. After joining, he found no record of what had been done so far concerning TPM. There was no evidence of any activity related to TPM seen at the shop floor. No real work was happening either on TPM or for Six Sigma. The company executives were expecting that the HOD Initiative should collect data, analyze it and give it to them. The unit head was also expecting almost the same type of cooperation under the pretext of supporting the HODs. The communication with the consultant was resumed, and they visited the factory and conducted another training programme and also took a review of the project status. The Six Sigma activities started gaining momentum, but it was too temporary. There used to be no review either by the Unit Head or at the MD level there. The unit head was of the opinion that the HOD-Initiative must make the partnership with the departmental people and pursue them to cooperate. Operators were indifferent and disengaged. There was no platform, either KAIZEN or any small group activities in the organization for the workmen.

There was an enormous problem in daily management. It was always a firefighting approach. HR issues were also very prominent. The HODs were so busy with routine problems that TPM and Six Sigma was an irritant to them. They were also suffering from Initiative-fatigue. There were no stated objectives of taking these initiatives. It was never seriously discussed with the unions. Workers were aloof from these activities, which was very much required particularly in the case of TPM. Attrition rate at the HOD -Initiative was also very high. The average shelf life of an incumbent was about 15 months. After a year, the present HOD- 
Initiative decided to leave at the end of 2010 out of frustration.

In the year 2010, just before leaving the then HOD-Initiative the company recruited a new plant manager to supplant the existing improvement-reluctant plant manager. It took almost six months to bring the next Black Belt as Head of Initiative on board. By that time, the new plant manager took control of the operations of the plant and was successful in convincing the father-son duo about his caliber. It took another year to buy in the interests of the chairman by a few presentations with the help of a few highly-reputed consultants on the approach and methodology of deployment. The seed of failure was planted when the HOD - Initiative was not at all involved in the consultant selection process and the methodology they adopted. The final selection of the consultant was against the preference of the plant manager as well. The consultant followed the same type of approach as the earlier consultants. As hard cash was not visible to the MD, he started losing interest, and without sincere, sustained influence from him, the project leaders began fumbling on the execution. With the tacit resistance from the plant level managers, the consultant started avoiding, after a few failed attempts, to continue the projects. Soon after, it came back to the previous state once the consultant stopped visiting and the MD stopped following up on the initiative and was formally buried once the Head - Initiative left the organization followed by the departure of the plant manager in 2014. As a result, the initiative took off multiple times with the arrival of different leaders but it could never get stability nor could it create an imprint on the people.

\section{Global Tyre (name changed)}

Global Tyre (GT) is an American multinational company having a presence in many countries across all continents. It has two manufacturing facilities in India besides their plants in Malaysia, Indonesia, Philippines, Thailand and China in the Asia Pacific zone. The case pertains to its India plants. The units are moderately automated and manned by reasonably formally trained operators. Manual work is minimum. Salary and wage level are relatively quite good with a good physical work environment and facilities like canteen, health care, etc. The company conceived the strategy of deploying Six Sigma in all their plants and operations across the world in 2002. They sent a few willing high performing employees from different functions to GT for thorough hands-on experience in the deployment of Six Sigma methodology from units across the world. After undergoing rigorous training and implementation of DMAIC methodology spread across several plants, the trained and certified Black Belts(BB) were deputed for developing a comprehensive two-week long classroom program for the Black Belts and Green Belts(GB) in-house. Black Belts were dedicated resources for executing black belt projects and facilitating projects. After a few cycles of Black Belt projects by the first batch of the Black Belts, they were further trained as trainers of Black Belt Programs and were groomed as Master Black Belts (MBB). The MBBs were then engaged in educating BBs and GBs in each plant. The Unit Head and his first line managers were intimately involved in the entire process of candidate selection, project selection, project execution and its review process. The weekly review used to be chaired by the CEO of the country/region and attended by the BB of the unit; Project Sponsors (usually the HODs); Project Leaders \& their key members; Project Champions and the plant head. The performance of the country/region CEOs, in turn, used to be reviewed by the Global CEO at a defined periodicity. The impact of the projects in the metrics used to be reported on a monthly basis after the metric data vetted by the factory appointed a cost accountant. As a result, the report on cost reduction/avoidance or other metrics that impacts the bottom lines used to be adequately authentic. The impact of each project used to be reported globally for twelve months to calculate the project impact before discontinuing the monitoring of the specific metric of the project. There was a high reward and recognition scheme in place.

\section{Analysis}

By going through the stories of the individual case study, theme wise vital points are noted below for each case.

Theme: Work environment and education level of the employees and plant level executives

Max Steel and Indo German Tubes

1. The work environment is not very conducive because of the hot work environment

2. Education level at the employee level is low but the plant managers and supervisors are professionally 
educated.

3. Facilities to employees are moderate, better than the sector average.

4. Manual work oriented processes

Pan India Glass

1. Education level at the employee level is low and at the plant managers and supervisors' level a few are professionally qualified and the majority are competent by experience only.

2. Facilities to employees are below average compared to other similar Industries.

3. Largely manual work.

Global Tyre

1. The moderately conducive work environment

2. Benchmark level facilities to employees and executives

3. Moderately automated work.

4. All are professionally qualified as per the job requirement.

Theme: Communication and Human Relation issues

Max Steel and Global Tyre

1. Communication with the employees by the plant management was formal, structured and open.

2. Communication within the management team was transparent with mutual trust

3. Communication with the corporate / Board level management and plant head was quite open as a result there was not much gap between perception and reality. Plant head enjoyed the confidence of the Chairman.

4. Moderately good Human relations.

Indo German Tubes

1. Communication with the employees by the plant management was moderate.

2. Communication within the management team was not transparent, mutual trust was also lacking.

3. Communication with the corporate / Board level management and plant head was strained coupled with fear and insecurity. As a result, there was a gap between the perception of the Board level and reality.

4. Moderately good Human relations.

\section{Pan India Glass}

1. The complete absence of formal Communication with the employees both by the plant management and corporate management.

2. Communication within the management team was not transparent with lack of mutual trust.

3. Communication with the corporate / Board level management and plant head was quite open. There was no gap between the perception and reality as chairman and MD are intimately involved with micromanagement.

4. Lot of unsolved Human relation issues.

5. No learning from other organizations.

6. Sense of urgency was not communicated and is totally missing.

Theme: Initiative related

All the cases are concerned with operational change initiatives, like TPM, Six Sigma and Small Group Activities.

Max Steel

1. Plant-wide and involved with all levels of management and employees

2. Objective of the initiatives was made clear to the employees 
3. Daily management was integrated with the initiatives

4. Project review and initiative status review system was quite strong.

5. According to our perception, we feel the Change Initiatives at Max Steel are successful

Indo German Tubes

1. Plant-wide and involved with all levels of management and employees

2. Objective of the initiatives was made clear to the employees

3. Project review and initiative status review system is not effective mainly due to input data to the review process does not represent the reality.

4. According to our perception the Change Initiatives at Indo German Tubes are not successful.

Pan India Glass

1. Plant-wide and involved with all levels of management

2. Nobody including the successive change agents knew the goal of introducing the initiatives, other than rhetoric like "we have to change the culture."

3. Complete absence of review mechanism.

4. According to our perception, the Change Initiatives at Pan India Glass are not successful.

Global Tyre

1. Plant-wide and predominantly executive driven. Global practices were followed.

2. The goal of the initiative is to achieve the strategic objectives and it was a case of great success.

3. Multilevel review mechanism was present.

4. The management took to change the course when they found the system was not working as desired after sometime and it was brought back to the high energy level.

We mapped the findings from the cases to the already established theory/steps, given in Table 1 , and presented in table 2 .

\section{Findings from the analysis}

We may summarise the findings from the analysis in below points

1. Out of the ten steps except, "Form partnership with stakeholders for guiding coalition" are supported by the case findings, which is also not supported by the scientific evidence.

2. Though systematic empirical evidence of institutionalization processes is lacking our findings strongly support the step "Institutionalize change" as in all successful change cases this practice is followed.

3. It came out very strongly from the five cases that if the basics of good management practices supported by the theories like Frederick Herzberg's 'Hygiene factor'; Henry Fayols' 14 principles of management particularly, Espirit de Corps, Discipline and Equity; (Van Vliet, 2009) and above all Deming's 'Drive out Fear' are not in place change management initiatives aiming higher level of managerial practices would not be successful. We feel "Ensure basic good management practices" are in place before taking up change initiatives.

\section{Conclusion}

Based on our hands-on experience in five organizations in India as a change agent we have taken a reflective exercise to recollect what was good and what was not good in each organization and tried to identify factors that have to be taken care of to make the change initiative a success. We mapped our findings against the existing change management theories. We found that all the theories are supported by the case study findings except the need of "Institutionalize change", which we find as an important step to sustain change. The existing theories and the steps are also silent on the need to have good management practices as a prerequisite for a successful change. Our experience suggests that if the basics of good management practice 
do not exist, the organization should not go for introducing the change related to management practices. Change initiatives are contextual but good management practice is not time depended and also depends little on the context of the organization. These findings will help both practitioners from industry and academicians get better insights on change management strategies.

\section{Implications}

\section{Theoretical:}

i) Though all the change models, available in the extant literature, have stressed on the need of institutionalization of change for successful implementation of change initiatives but systematic empirical evidence of institutionalization processes as a requirement is lacking in the extant literature. This study fills this gap by comparing the companies, who are successful in implementing change initiative with the companies, who are not successful in implementing the change initiatives.

ii) The existing theories and the steps are also silent on the need to have good management practices as a prerequisite for a successful change. Our experience from the case studies suggests that if the basics of good management practices do not exist in an organization, it will be challenging for such organizations to implement change initiatives successfully.

iii) One of the steps of the ten steps process of Prescriptive Change Models, 'Form partnership with stakeholders for guiding coalition', as available in the extant literature, is not supported by our case study findings. There is no scientific evidence in support of the requirement of this step. Thus our study reinforces that this step may not be a requirement for implementation of change initiatives successfully.

Practical:

i) The practitioners shall ensure that "basic good management practices" are in place before taking up change initiatives. This will save the organisations from spending time, effort and money in taking the initiatives to implement any organisation wide change practice(s).

ii) The compelling stories presented from the five case studies in the paper will give an insight to the practitioners as to how they should go about introducing changed processes.

\section{Future scope of studies}

We have used narrative inquiry based on memory as we are part of the system in each organisation. This has advantages as mentioned in the methodology section. It has also its disadvantages. We may get biased. Though we have consciously tried our best not to get biased by taking first our individual stand then arrived at a consensus still cognitive biases may crop in. Secondly, as our study is based on memory it is subject to error as human memory is unreliable with time (Wixted, J. T, et al., 2018). Hence, a multiple case study based research following a different methodology by independent researcher may be carried out and the findings may be compared with the present study findings. Such an approach will help generalize the findings more reliably.

Table 1: Ten Steps Summary of Prescriptive Change Models

\begin{tabular}{|l|l|l|}
\hline \multicolumn{1}{|c|}{ Step } & \multicolumn{1}{|c|}{ Scientific evidence } & Remarks \\
\hline Identify and assess the & The need for assessing the \\
opportunity to be exploited & opportunity or problems to \\
or problem to be solved that & be solved are well supported \\
motivates change to happen & by the research in the area of \\
with a sense of urgency & $\begin{array}{l}\text { decision making and problem } \\
\text { solving but 'sense of }\end{array}$ & urgency'is not supported. On \\
the contrary, urgency & increases employee stress \\
level, which become an & obstacle to facilitate change \\
management.
\end{tabular}




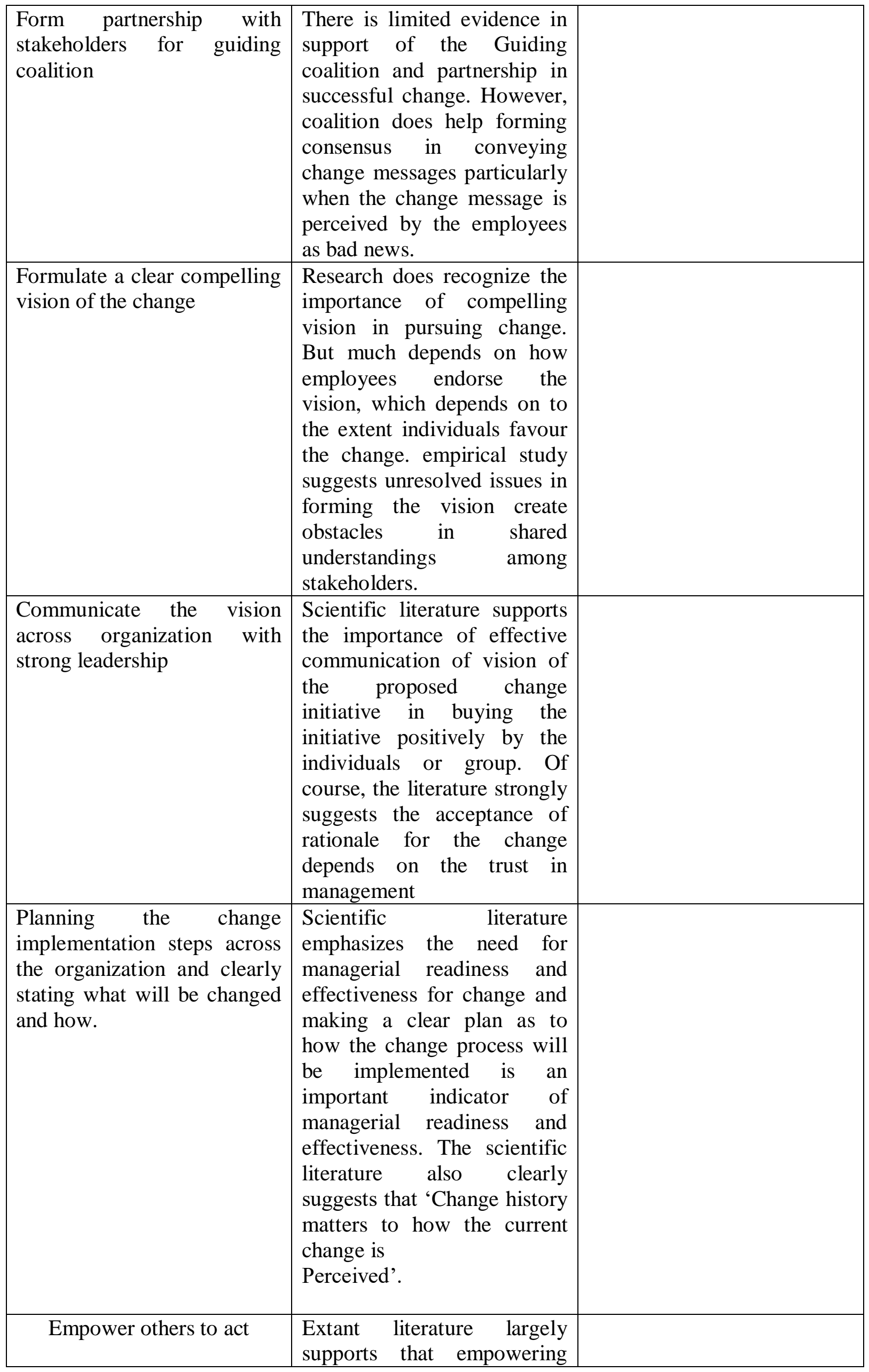




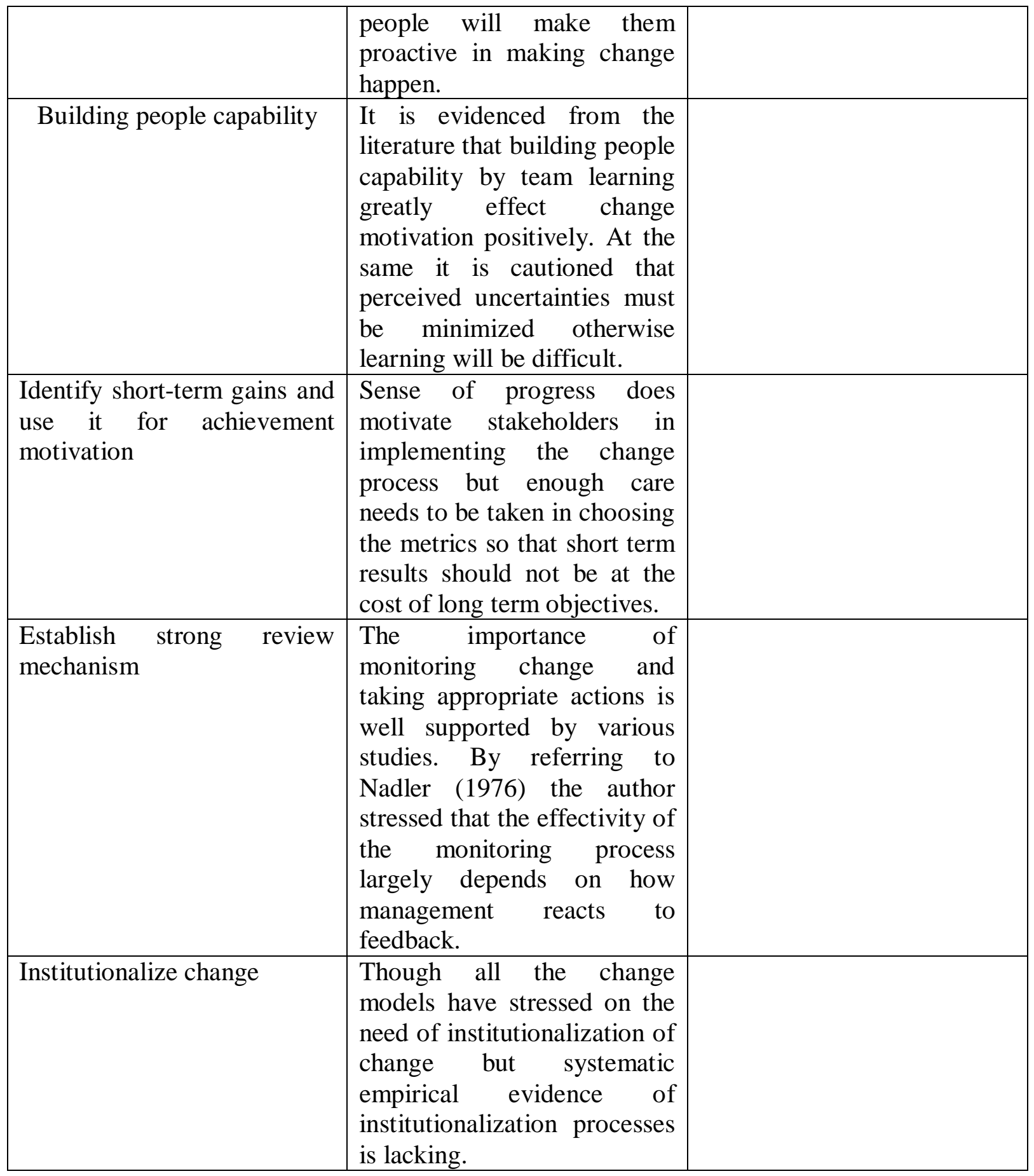




\begin{tabular}{|c|c|c|c|}
\hline Step & Scientific evidence & Case findings & Remarks \\
\hline $\begin{array}{l}\text { Identify and assess the } \\
\text { opportunity to be } \\
\text { exploited or problem to } \\
\text { be solved that } \\
\text { motivates change to } \\
\text { happen with a sense of } \\
\text { urgency }\end{array}$ & $\begin{array}{l}\text { The need for assessing } \\
\text { the opportunity or } \\
\text { problems to be solved } \\
\text { are well supported by the } \\
\text { research in the area of } \\
\text { decision making and } \\
\text { problem solving but } \\
\text { 'sense of urgency' is not } \\
\text { supported. On the } \\
\text { contrary, urgency } \\
\text { increases employee } \\
\text { stress level, which } \\
\text { become an obstacle to } \\
\text { facilitate change } \\
\text { management. }\end{array}$ & $\begin{array}{l}\text { Both the issues: } \\
\text { need for assessing } \\
\text { the opportunity and } \\
\text { sense of urgency are } \\
\text { supported in our } \\
\text { studies. } \\
\text { As for example in } \\
\text { case of Pan India } \\
\text { Glass both were } \\
\text { absent. We have not } \\
\text { examined the level } \\
\text { of stress on the } \\
\text { employees in other } \\
\text { cases where sense } \\
\text { of urgency was } \\
\text { placed. }\end{array}$ & \\
\hline $\begin{array}{lr}\text { Form partnership } & \text { with } \\
\text { stakeholders } & \text { for } \\
\text { guiding coalition } & \end{array}$ & $\begin{array}{l}\text { There is limited } \\
\text { evidence in support of } \\
\text { the Guiding coalition } \\
\text { and partnership in } \\
\text { successful change. } \\
\text { However, coalition does } \\
\text { help forming consensus } \\
\text { in conveying change } \\
\text { messages particularly } \\
\text { when the change } \\
\text { message is perceived by } \\
\text { the employees as bad } \\
\text { news. }\end{array}$ & $\begin{array}{l}\text { Our findings do not } \\
\text { corroborate with the } \\
\text { idea of forming } \\
\text { partnership. } \\
\text { Wherever it was a } \\
\text { success, no such } \\
\text { effort was made to } \\
\text { form 'Partnership } \\
\text { with stakeholders.' }\end{array}$ & \\
\hline $\begin{array}{l}\text { Formulate a clear } \\
\text { compelling vision of } \\
\text { the change }\end{array}$ & $\begin{array}{l}\text { Research does recognize } \\
\text { the importance of } \\
\text { compelling vision in } \\
\text { pursuing change. But } \\
\text { much depends on how } \\
\text { employees endorse the } \\
\text { vision, which depends } \\
\text { on to the extent } \\
\text { individuals favour the } \\
\text { change. Empirical study } \\
\text { suggests unresolved } \\
\text { issues in forming the } \\
\text { vision create obstacles in } \\
\text { shared understandings } \\
\text { among stakeholders. }\end{array}$ & $\begin{array}{l}\text { The scientific } \\
\text { evidence is highly } \\
\text { supported by our } \\
\text { findings. As for } \\
\text { example Pan India } \\
\text { Glass did not have } \\
\text { any vision for } \\
\text { change. And in case } \\
\text { of Indo German } \\
\text { Tubes though vision } \\
\text { was articulated but } \\
\text { there were many } \\
\text { unresolved issues, } \\
\text { which are quite } \\
\text { clear from the } \\
\text { stories presented } \\
\text { and also in the } \\
\text { Analysis. }\end{array}$ & $\begin{array}{l}\text { We feel, it is } \\
\text { very important } \\
\text { to ensure basics } \\
\text { are in place. The } \\
\text { management } \\
\text { must ensure } \\
\text { before } \\
\text { introducing } \\
\text { change } \\
\text { initiatives that } \\
\text { the good } \\
\text { management } \\
\text { practices } \\
\text { Frederick } \\
\text { Herzberg's } \\
\text { 'Hygiene factor'; } \\
\text { Henry Fayols' } \\
14 \text { principles of } \\
\text { management }\end{array}$ \\
\hline
\end{tabular}




\begin{tabular}{|c|c|c|c|}
\hline & & & $\begin{array}{l}\text { particularly, } \\
\text { Espirit de Corps, } \\
\text { Discipline and } \\
\text { Equity; (Van } \\
\text { Vliet, 2009) and } \\
\text { above all } \\
\text { Deming's 'Drive } \\
\text { out Fear' are in } \\
\text { place. Though } \\
\text { this point may } \\
\text { be implicit in } \\
\text { 'unresolved } \\
\text { issues' } \\
\text { mentioned in the } \\
\text { Scientific } \\
\text { evidence but in } \\
\text { Indian context } \\
\text { this point needs } \\
\text { to be explicitly } \\
\text { mentioned. In } \\
\text { the big picture } \\
\text { view, Andreeva } \\
\text { et al., (2016) has } \\
\text { addressed the } \\
\text { issue but the } \\
\text { point was not } \\
\text { explicitly } \\
\text { pointed out. }\end{array}$ \\
\hline $\begin{array}{lr}\text { Communicate } & \text { the } \\
\text { vision } & \text { across } \\
\text { organization } & \text { with } \\
\text { strong leadership } & \end{array}$ & $\begin{array}{l}\text { Scientific literature } \\
\text { supports the importance } \\
\text { of effective } \\
\text { communication of vision } \\
\text { of the proposed change } \\
\text { initiative in buying the } \\
\text { initiative positively by } \\
\text { the individuals or group. } \\
\text { Of course, the literature } \\
\text { strongly suggests the } \\
\text { acceptance of rationale } \\
\text { for the change depends } \\
\text { on the trust in } \\
\text { management }\end{array}$ & $\begin{array}{l}\text { Quality of } \\
\text { leadership and trust } \\
\text { in management are } \\
\text { strongly supported } \\
\text { in all the cases. As } \\
\text { for example, though } \\
\text { Max Steel and Indo } \\
\text { German Tubes both } \\
\text { are under the same } \\
\text { group company, in } \\
\text { Indo German } \\
\text { Tubes, trust in } \\
\text { management was } \\
\text { totally lacking at all } \\
\text { levels. }\end{array}$ & \\
\hline $\begin{array}{l}\text { Planning the change } \\
\text { implementation steps } \\
\text { across the organization } \\
\text { and clearly stating what } \\
\text { will be changed and } \\
\text { how. }\end{array}$ & $\begin{array}{l}\text { Scientific literature } \\
\text { emphasizes the need for } \\
\text { managerial readiness and } \\
\text { effectiveness for change } \\
\text { and making a clear plan } \\
\text { as to how the change } \\
\text { process will be } \\
\text { implemented is an } \\
\text { important indicator of } \\
\text { managerial readiness and }\end{array}$ & $\begin{array}{l}\text { Not only 'Why' and } \\
\text { 'What' } \\
\text { important in case of } \\
\text { change } \\
\text { management. How } \\
\text { is also very } \\
\text { important. }\end{array}$ & \\
\hline
\end{tabular}




\begin{tabular}{|c|c|c|}
\hline & $\begin{array}{l}\text { effectiveness. } \\
\text { scientific literature also } \\
\text { clearly suggests that } \\
\text { 'Change history matters } \\
\text { to how the current } \\
\text { change is } \\
\text { Perceived'. }\end{array}$ & \\
\hline Empower others to act & $\begin{array}{l}\text { Extant literature largely } \\
\text { supports that } \\
\text { empowering people will } \\
\text { make them proactive in } \\
\text { making change happen. }\end{array}$ & $\begin{array}{l}\text { Empowerment is a } \\
\text { positive factor for } \\
\text { successful } \\
\text { implementation of } \\
\text { change initiatives. } \\
\text { Small group activity } \\
\text { in all the successful } \\
\text { cases have strong } \\
\text { small group } \\
\text { activities. }\end{array}$ \\
\hline $\begin{array}{l}\text { Building people } \\
\text { capability }\end{array}$ & $\begin{array}{l}\text { It is evidenced from the } \\
\text { literature that building } \\
\text { people capability by } \\
\text { team learning greatly } \\
\text { effect change motivation } \\
\text { positively. At the same it } \\
\text { is cautioned that } \\
\text { perceived uncertainties } \\
\text { must be minimized } \\
\text { otherwise learning will } \\
\text { be difficult. }\end{array}$ & $\begin{array}{l}\text { Building people } \\
\text { capability is a } \\
\text { primary step to } \\
\text { implement change. } \\
\text { All successful } \\
\text { companies like, } \\
\text { Max Steel and } \\
\text { Global Tyre are two } \\
\text { supportive } \\
\text { examples. But only } \\
\text { empowerment is not } \\
\text { enough. As for } \\
\text { example, Indo } \\
\text { German Tube has } \\
\text { also given equal } \\
\text { amount of training } \\
\text { to employees like } \\
\text { Max steel but they } \\
\text { could not } \\
\text { implement the } \\
\text { change initiatives. }\end{array}$ \\
\hline $\begin{array}{l}\text { Identify short-term } \\
\text { gains and use it for } \\
\text { achievement motivation }\end{array}$ & $\begin{array}{l}\text { Sense of progress does } \\
\text { motivate stakeholders in } \\
\text { implementing the change } \\
\text { process but enough care } \\
\text { needs to be taken in } \\
\text { choosing the metrics so } \\
\text { that short term results } \\
\text { should not be at the cost } \\
\text { of long-term objectives. }\end{array}$ & $\begin{array}{l}\text { We could not } \\
\text { investigate } \\
\text { point. }\end{array}$ \\
\hline $\begin{array}{l}\text { Establish strong review } \\
\text { mechanism }\end{array}$ & $\begin{array}{l}\text { The importance of } \\
\text { monitoring change and } \\
\text { taking appropriate } \\
\text { actions is well supported } \\
\text { by various studies. By }\end{array}$ & $\begin{array}{l}\text { Need of strong } \\
\text { review mechanism } \\
\text { has come out very } \\
\text { strongly by analysis } \\
\text { all the cases. All the }\end{array}$ \\
\hline
\end{tabular}




\begin{tabular}{|c|c|c|}
\hline & $\begin{array}{l}\text { referring to Nadler } \\
\text { (1976) author stressed } \\
\text { that the effectivity of the } \\
\text { monitoring process } \\
\text { largely depends on how } \\
\text { management reacts to } \\
\text { feedback. }\end{array}$ & $\begin{array}{l}\text { successful } \\
\text { companies like Max } \\
\text { Steel and Global } \\
\text { Tyre had strong } \\
\text { review mechanism. } \\
\text { Indo German Tubes } \\
\text { was having similar } \\
\text { review mechanism } \\
\text { like Max Steel but it } \\
\text { was not effective as } \\
\text { the input to the } \\
\text { review system was } \\
\text { all false and lack of } \\
\text { trust and fear are } \\
\text { attributed to this } \\
\text { false input. Pan } \\
\text { India Glass was not } \\
\text { having any review } \\
\text { mechanism. }\end{array}$ \\
\hline Institutionalize change & $\begin{array}{l}\text { Though all the change } \\
\text { models have stressed on } \\
\text { the need of } \\
\text { institutionalization of } \\
\text { change but systematic } \\
\text { empirical evidence of } \\
\text { institutionalization } \\
\text { processes is lacking. }\end{array}$ & $\begin{array}{l}\text { Our findings go in } \\
\text { line with the } \\
\text { prescriptive models, } \\
\text { in this regard. All } \\
\text { successful } \\
\text { companies from the } \\
\text { case studies, made } \\
\text { change initiative as } \\
\text { a part of regular } \\
\text { activity by formally } \\
\text { integrating it with } \\
\text { the system. }\end{array}$ \\
\hline
\end{tabular}

\section{References}

[1] Barends, E., Janssen, B., ten Have, W., \& ten Have, S. ( 2013) Effects of change interventions: What kind of evidence do we really have? Journal of Applied Behavioral Science, 50, pp. 28-33.

[2] Beer, M. (1980) Organization change and development: A systems view. Santa Monica, CA: Goodyear.

[3] Bell, J. (1999) Doing your research project - a guide for first time researchers. In: Education and Social Science. 3rd ed. Buckingham: Open University Press.

[4] Clark, A. and Chalmers, D. (1998) The extended mind. Analysis, 58(1), pp.7-19.

[5] Cole, C., Chase, S., Couch, O., and Clark, M. (2011) Research methodologies and professional practice: considerations and practicalities. The Electronic Journal of Business Research Methods, 9(2), pp.141-151.

[6] Cooperrider, D. L., \& Srivastva, S. (1987) Appreciative inquiry in organizational life. In R.W.Woodman \& W.A.Pasmore (Eds.), Research in organizational change and development,pp. 129169. Greenwich, CT: JAI Press.

[7] Doolin, B. (1996) Alternative views of case research in information systems. Aust J Inf Syst, 3(2), pp.21-29

[8] Hiatt, J. M. (2006) ADKAR:Amodel for change in business, government and our community: How to implement successful change in our personal lives and professional careers. Loveland, CO: Prosci Research. 
[9] Judson, A. (1991) Changing behaviour in organizations: Minimizing resistance to change. Cambridge, MA: Basil Blackwell.

[10] Kanter, R. M., Stein, B. A, \& Jick, T. D. (1992) The challenge of organizational change: How companies experience it and leaders guide it. New York: Free Press.

[11] Kotter, J. (1995). Leading change: why transformation efforts fail. Harvard Business Review, March/April, pp.59-68.

[12] Moher D, Liberati A, Tetzlaff J, Altman DG ( 2010) Preferred reporting items for systematic reviews and meta-analyses: the PRISMA statement, Int J Surg.8(5), pp. 336-341.

[13] Price C, Lawson E, ( 2003) The Psychology of Change Management The McKinsey Quarterly, 2 Organization

[14] Sarayreh, B.H, Hassan J A, Barakat A E (2013), Comparative Study: The Kurt Lewin of Change Management, International Journal of Computer and Information Technology,2(4),pp.626-629.

[15] Stake, R. (1995). The art of case study research. Thousand Oaks, CA: Sage,pp.49-68.

[16] Stouten J, Rousseau D M (2018) Successful organizational change: Integrating the management practice and scholarly literatures, Academy of Management Annals 12(2), pp.752-788.

[17] Change management, inside job. The Economist, May 10, 2001.

[18] Van Vliet, V. (2009). 14 Principles of management (Fayol). [online] Available at: <https://www.toolshero.com/management/14-principles-of-management/> [Accessed 6 October 2018]

[19] Wixted, J. T., Mickes, L., \& Fisher, R. P. (2018). Rethinking the Reliability of Eyewitness Memory. Perspectives on Psychological Science, 13(3), 324-335. 